\title{
Study the Indicators of Germination and Growth of Some Species of Weeds under Different Thermal Conditions.
}

\author{
Muhammad AL SAKRAN *, Kamal ALMHEMED, Tamer USTUNER \\ Department of Plant Protection, Faculty of Agriculture Kahramanmaras Sutcu Imam University, \\ Kahramanmaras, Turkey
}

*Corresponding Authors:Muhammad AL SAKRAN,Department of Plant Protection, Faculty of Agriculture KahramanmarasSutcu Imam University, Kahramanmaras, Turkey

\begin{abstract}
The aim of this study is to determine the effect of temperature on the germination and growth indices of some species of weeds in laboratory conditions. The tested species were Amaranthusretroflexus L., Amaranthusblitoides S., Euphorbia maculata L., Portulacaoleracea L. and CuscutacampestrisYunck. To achieve this goal, the germination rate (GR), speed of germination (SG), Mean germination time (MGT), and the daily growth rate of seedlings (DGR) were calculated. The results showed that increasing temperatures to $35^{\circ} \mathrm{C}$ increases the value of the studied indicators. There was no significant difference between thermal treatments for A. retroflexus, the percentage of germination in all treatment was high, but there was a significant difference in other indicators. There was no germination of the species E. maculata, P. oleracea and $C$. campestris at $17^{\circ} \mathrm{C}$ during the trial period. The germination rate increased with increasing temperature. E. maculata was the most tested species affected by low temperature. The results of this study confirm the role of temperature in the beginning of the emergence and speed of development of the weed population, especially that some species show great response to thermal differences.
\end{abstract}

Keywords: Weeds, germination rate, speed of germination, mean germination time, daily growth rate of seedlings

\section{INTRODUCTION}

Germination of seeds is affected by many internal and external factors. The main external factors affecting seed's germination are oxygen, water, light, and temperature (Manoto et al., 2004). The temperature is one of the most important external factors that effect on seed's germination. Whereas, at low temperatures, the germination rate decreases, and with rising temperatures, this rate increases until it reaches the optimum level, but with the high temperature above this limit, the germination rate decreases as a result of the damage in the seeds (Fu et al., 2017). The appropriate temperature for most seeds to germinate is between 15 and $30{ }^{\circ} \mathrm{C}$. The effect of temperature depends on several factors, including the species, varieties, growth areas, seed's quality, and the period after the harvest (Shaban, 2013). It was noted that there was no germination of $P$. oleracea seeds at temperature $5 \mathrm{C}^{\circ}$ and the germination rate was very low at temperature $10 \mathrm{C}^{\circ}$ and the best temperature for germination was at $30 \mathrm{C}^{\circ}$ ( Ustuner, 2002). A study conducted on the seeds of P. oleracea to determine the influence of temperatures on seed's germination in the lab conditions reported that the germination percentage in the dark/dark system was $81 \%$ at $\left(25 / 15^{\circ} \mathrm{C}\right)$, while in the light/dark system, the germination was $70 \%$ at $\left(25 / 15^{\circ} \mathrm{C}\right)$ ( Chauhan and Johnson, 2009). In other study to determine the effect of temperatures on seed germination in A. retroflexus, the results showed that the minimum temperature for seed germination was $>5 \mathrm{C}$; maximum germination occurred between 35 and $40 \mathrm{C}$ (Ghorbani et al, 2017). The effects of temperature on seed's germination of nine Amaranthus species were tested under constant and rotating temperature regimens at $5,10,15,20,25,30$, and $35^{\circ} \mathrm{C}$. It has been reported that the constant and rotating temperatures regimens increased total germination of all Amaranthus species (Lawrence et al, 2004). A search was conducted to assess the influence of temperature on seed germination of E. immaculate. Where it was found that seeds germinated over a constant temperature estimated of 25 to $45^{\circ} \mathrm{C}$ with a 14 -h photoperiod and at 30 to $50^{\circ} \mathrm{C}$ in continuous darkness with higher germination value reached $80 \%$ (Rayhaneh et al, 2015). In laboratory conditions, 
and in an experiment to break the dodder ( $C$. campestris) seed's dormancy, the germination percentage of the dodder seeds reached to $60 \%$ with the treatment of $\mathrm{H} 2 \mathrm{SO} 4$ under temperature $25^{\circ} \mathrm{C}$ (Ustuner and Cakir 2019; Almhemed et al, 2020). It was reported that the best method to break dormancy of Johnson grass seeds through removing the seed coat, then, treatment of seeds with gibberellic acid under temperature $28^{\circ} \mathrm{C}$ that would increase germination rates (AL sakran et al, 2020).

\section{Materials AND Methods}

This experiment was performed in 2020 in the laboratories of the Kahramanmaras Sutcu Imam University, Agriculture Faculty, Department of Plant Protection. The experiment lasted three weeks and data was taken daily. Tested species were Amaranthus retroflexus L., A. blitoides S., Euphorbia maculata L., Portulaca oleracea L. and Cuscuta campestris Yunck. Their seeds were collected in 2019 from fields in the Kahramanmaras governorate, Onikisubat district. The seeds were kept in the weed laboratory at $20^{\circ} \mathrm{C}$ in paper bags. Germination chambers were set to $15,23,28,35^{\circ} \mathrm{C}$ and 12:12 hours of lighting and darkness. Petri dishes were prepared by placing double filter papers in it and moisturized with $7 \mathrm{ml}$ distilled water. Seeds of species were disinfected with $\mathrm{NaCl} 1 \%$ solution then washed with distilled water. For every species 30 seeds were placed in each petri dish and experiment was designed as a completely randomized design, and each treatment were replicated 3 times. Data were analyzed by ANOVA and LSD $(p<0.05)$. Before starting this experiment, the seeds of the species were tested if they were in dormancy and it was found that, exception of dodder, all species were biologically active and able to germinate with a high rate at a temperature of 28 and lit 12:12 hours. Therefore, the dodder seeds were exposed to concentrated sulfuric acid to break the dormancy then it was treated with gibberellic acid (Almhemed et al, 2020; AL Sakran et al, 2020).Germination rate for species were calculated for according to the following formula:

$\mathrm{GR}=$ (germinated seeds number/ total number of seeds $) \times 100$

While mean germination time (MGT) were calculate by following formula for every species:

$\operatorname{MGT}=\frac{\sum(D n)}{N}$.

Where n: number of seeds germinated on each day, d: number of days from the beginning of the test and $\mathrm{N}$ : total number of seeds germinated at the termination of the experiment (Ellis and Roberts, 1981).

Speed of germination (SG) was calculated according to (ISTA., 1999) using the following formula:

$\mathrm{SG}=\mathrm{n} 1 / \mathrm{d} 1+\mathrm{n} 2 / \mathrm{d} 2+\mathrm{n} 3 / \mathrm{d} 3+----$

Note, $\mathrm{n}=$ Germinated seed's number, $\mathrm{d}=$ Day's number

The high temperature leads to faster germination as well as faster growth. Where it was found through the experiment that the treatment with high temperature reached the maximum rate of germination and growth during a short period compared to the treatment of the lower temperature that continued to grow until the end of the experiment. To determine the daily growth rate, we suggest the following equation:

$\mathrm{DGR}=\sum \mathrm{Lx} /(\mathrm{d}+3) \times \mathrm{GS}$

DGR: Daily growth rate

Lx: the length of seedling three days after the end of germination, d: The number of germination days +3 , GS: Number of germinated seeds

According to the equation, the seedlings that grew in the last days will not have reached the highest level of growth. So, it waited 3 days for it to grow. This equation may not be accurate, but it gives an indication of how fast the growth is.

Collected data were analyzed using SPSS and analysis of variance (ANOVA) at $1 \%$ level of probability.

\section{RESULT AND DISCUSSION}

There was no significant effect of temperature on the seed germination rate for A. retroflexus, and 
ranged between $84.93 \%$ for $17^{\circ} \mathrm{C}$ and $89.58 \%$ for $32^{\circ} \mathrm{C}$ (Figure 1). However, the mean germination time (MGT) was greatly affected, ranging between 9 days for the treatment of $17^{\circ} \mathrm{C}$ and 3.3 days for $32^{\circ} \mathrm{C}$, there were significant differences between all treatments (Table 1). Likewise, there were significant differences in germination speed (SG) between treatments except $23^{\circ} \mathrm{C}$ and $28^{\circ} \mathrm{C}$ and the highest germination speed was in treatment $32^{\circ} \mathrm{C}$ where it was 9.6 germinated seeds/day and the lowest in treatment $17{ }^{\circ} \mathrm{C} 3.53$ germinated seeds/day (Table 2). The seedlings showed a positive response to the increase in temperature and recorded the highest daily growth rate at $32^{\circ} \mathrm{C} 0.46 \mathrm{~cm} /$ day and the lowest was at a temperature of $17^{\circ} \mathrm{C} 0.182 \mathrm{~cm} /$ day (Table 3).

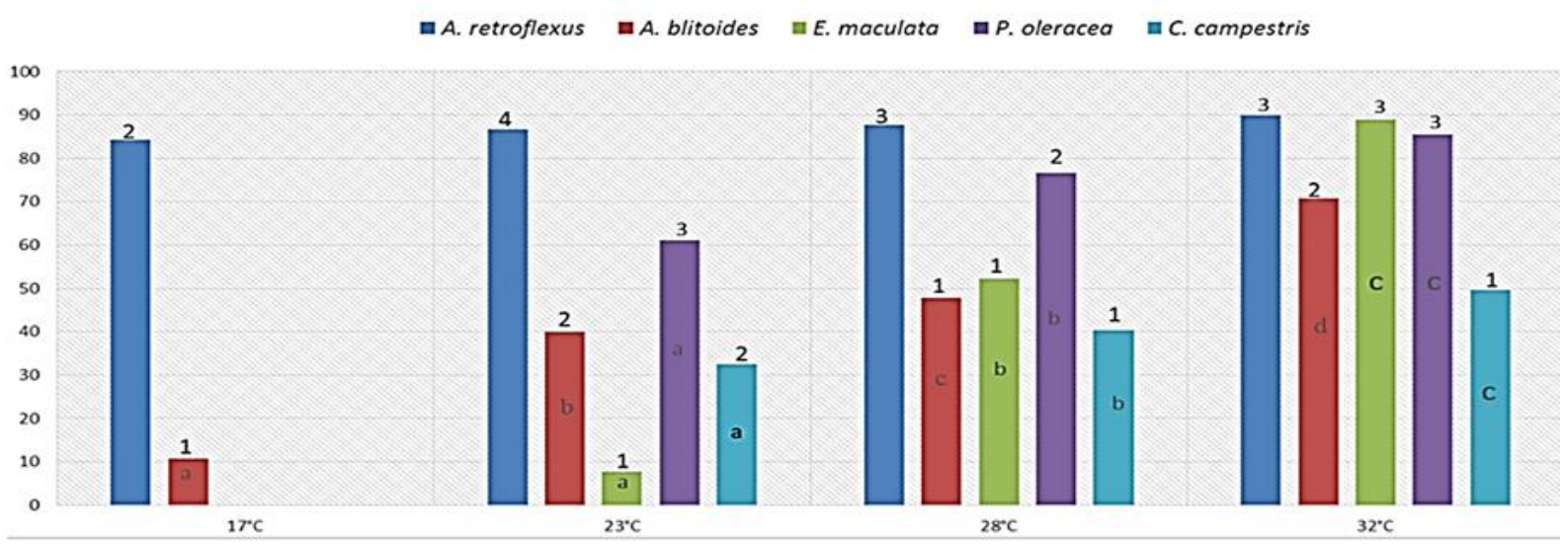

Figure1.Species germination rate $(G R)$ at different temperatures

a, b, c - means followed by the same letter within the same species and different temperature are not significantly different at $\mathrm{P}<0.05$.

1,2,3- means followed by the same number within the same temperature between species are not significantly different at $\mathrm{P}<0.05$.

Unlike A. retroflexus, the seed germination ratio of $A$. blitoides was affected by temperature and there was a significant difference between all treatments. The germination percentage ranged between 10.72 and $70.78 \%$ for treatments $17^{\circ} \mathrm{C}$ and $32^{\circ} \mathrm{C}$, respectively (Figure 1). The mean germination time ranged between 10.11 and 6.48 days for temperatures $17^{\circ} \mathrm{C}$ and $32^{\circ} \mathrm{C}$, respectively, with a significant difference between all treatments (Table 1). The highest germination speed was 3.6 seed germinated / day at temperature $32^{\circ} \mathrm{C}$ and the lowest was 0.277 seed germinated / day at $17^{\circ} \mathrm{C}$, there was significant difference for all temperatures on germination speed (Table 2). There was no significant difference in the daily growth rate of seedlings between converging temperatures except for treatment $17^{\circ} \mathrm{C}$ where the daily growth rate was $0.396 \mathrm{~cm} /$ day and the highest daily growth rate was $0.535 \mathrm{~cm} /$ day at temperature $32^{\circ} \mathrm{C}$ (Table 3 ).

Table1. Mean germination time (MGT) for species at different temperatures

\begin{tabular}{|c|c|c|c|c|c|}
\hline Temperatures & A. retroflexus & A. blitoides & E. maculata & P. oleracea & C. campestris \\
\hline $\mathbf{1 7}^{\circ} \mathbf{C}$ & $9^{\mathrm{a}}{ }_{1}$ & $10.11^{\mathrm{a}}{ }_{2}$ & - & - & - \\
\hline $\mathbf{2 3}^{\circ} \mathbf{C}$ & $7.06^{\mathrm{b}}{ }_{1}$ & $7.93^{\mathrm{b}}{ }_{1}$ & $12.89^{\mathrm{a}}{ }_{2}$ & $10.39^{\mathrm{a}}{ }_{3}$ & $8.36^{\mathrm{a}}{ }_{1}$ \\
\hline $\mathbf{2 8}^{\circ} \mathbf{C}$ & $6.16^{\mathrm{c}}{ }_{1}$ & $7.23^{\mathrm{c}}{ }_{2}$ & $11.91^{\mathrm{b}}{ }_{3}$ & $9.22^{\mathrm{b}}{ }_{4}$ & $5.23^{\mathrm{b}}{ }_{1}$ \\
\hline $\mathbf{3 2}^{\circ} \mathbf{C}$ & $3.3^{\mathrm{d}}{ }_{1}$ & $6.48^{\mathrm{d}}{ }_{3}$ & $8.45^{\mathrm{c}}{ }_{4}$ & $3.79^{\mathrm{c}}{ }_{1}$ & $4.51^{\mathrm{b}}{ }_{2}$ \\
\hline
\end{tabular}

$\mathrm{a}, \mathrm{b}, \mathrm{c}$ - means followed by the same letter within the same species and different temperature are not significantly different at $\mathrm{P}<0.05$.

1,2,3- means followed by the same number within the same temperature between species are not significantly different at $\mathrm{P}<0.05$.

No germination was observed for E. maculata seeds at $17^{\circ} \mathrm{C}$, lowest germination rate was $7.78 \%$ for $23^{\circ} \mathrm{C}$. However, with increased temperature, germination rate increased to $88.89 \%$ at $32^{\circ} \mathrm{C}$ (Figure 1). The mean germination time ranged from 12.89 to 8.45 days for temperatures $23^{\circ} \mathrm{C}$ and $32^{\circ} \mathrm{C}$, respectively, and there was a significant difference between the treatments (Table 1). The speed of germination was also affected by the temperature differences. There was a significant difference between the germination speed at different temperatures and the highest speed was 3.55 at 
Study the Indicators of Germination and Growth of Some Species of Weeds under Different Thermal Conditions.

temperature $32^{\circ} \mathrm{C}$ and lowest 0.2 seed germinated/day at temperature $23^{\circ} \mathrm{C}$ (Table 2). The daily growth rate of seedlings ranged between 0.188 and $0.299 \mathrm{~cm} /$ day and there was no significant difference between treatments $28^{\circ} \mathrm{C}$ and $32^{\circ} \mathrm{C}$ (Table 3).

Table2.Speed of germination (SG) of species at different temperatures

\begin{tabular}{|c|c|c|c|c|c|}
\hline Temperatures & A. retroflexus & A. blitoides & E. maculata & P. oleracea & C. campestris \\
\hline $\mathbf{1 7}^{\circ} \mathbf{C}$ & $3.53^{\mathrm{a}}{ }_{1}$ & $0.277^{\mathrm{a}}{ }_{2}$ & - & - & - \\
\hline $\mathbf{2 3}^{\circ} \mathbf{C}$ & $4.241 \mathrm{a}^{\mathrm{b}}{ }_{3}$ & $1.612^{\mathrm{b}}{ }_{2}$ & $0.2^{\mathrm{a}}{ }_{1}$ & $1.889^{\mathrm{a}}{ }_{2}$ & $0.778^{\mathrm{a}}{ }_{1}$ \\
\hline $\mathbf{2 8}^{\circ} \mathbf{C}$ & $4.8 \mathrm{a}^{\mathrm{b}}{ }_{3}$ & $2.184^{\mathrm{b}}{ }_{1}$ & $1.405^{\mathrm{b}}{ }_{1}$ & $2.721^{\mathrm{b}}{ }_{2}$ & $1.972^{\mathrm{b}}{ }_{1}$ \\
\hline $\mathbf{3 2}^{\circ} \mathbf{C}$ & $9.6^{\mathrm{c}}{ }_{4}$ & $3.6^{\mathrm{c}}{ }_{2}$ & $3.552_{\mathrm{c}}{ }^{2}$ & $7.117^{\mathrm{c}}{ }_{3}$ & $2.22^{\mathrm{b}}{ }_{1}$ \\
\hline
\end{tabular}

$\mathrm{a}, \mathrm{b}, \mathrm{c}$ - means followed by the same letter within the same species and different temperature are not significantly different at $\mathrm{P}<0.05$.

1,2,3- means followed by the same number within the same temperature between species are not significantly different at $\mathrm{P}<0.05$.

No germination occurred in treatment $17^{\circ} \mathrm{C}$ for $P$. oleracea seeds, and the germination rate at $23^{\circ} \mathrm{C}$ was 61.11 and $85.56 \%$ at treatment $32^{\circ} \mathrm{C}$ with significant differences between treatments (Figure 1). The mean germination time was 3.79 days at temperature $32^{\circ} \mathrm{C}$ and 10.39 days at $23^{\circ} \mathrm{C}$ (Table 1 ). Germination speed varied significantly and was 1,889 in treatment $23^{\circ} \mathrm{C}$ and 7.117 in treatment $32^{\circ} \mathrm{C}$ (Table 2). There was no significant difference between the daily growth rate in treatments $23^{\circ} \mathrm{C}$ and $28^{\circ} \mathrm{C}$, while there was a significant difference between them and treatment $32^{\circ} \mathrm{C}$, and the daily growth rate of seedlings ranged between 0.123 and $3.94 \mathrm{~cm}$ for transactions $23^{\circ} \mathrm{C}$ and $32^{\circ} \mathrm{C}$, respectively (Table $3)$.

Table3. Daily growth rate (DGR) of species at different temperatures

\begin{tabular}{|c|c|c|c|c|c|}
\hline Temperatures & A. retroflexus & A. blitoides & E. maculata & P. oleracea & C. campestris \\
\hline $17^{\circ} \mathrm{C}$ & $0.182^{\mathrm{a}}{ }_{1}$ & $0.396_{2}^{\mathrm{a}}$ & - & - & - \\
\hline $23^{\circ} \mathrm{C}$ & $0.297^{\mathrm{b}}{ }_{2}$ & $0.517^{\mathrm{b}}{ }_{3}$ & $0.188^{\mathrm{a}}{ }_{2}$ & $0.123_{2}^{\mathrm{a}}$ & $0.231_{1}^{\mathrm{a}}$ \\
\hline $28^{\circ} \mathrm{C}$ & $0.327^{\mathrm{c}}{ }_{3}$ & $0.534^{\mathrm{bc}}{ }_{4}$ & $0.262^{\mathrm{b}}{ }_{2}$ & $0.154^{\mathrm{a}}$ & $0.377_{3}^{\mathrm{b}}$ \\
\hline $32^{\circ} \mathrm{C}$ & $0.462^{\mathrm{d}}{ }_{2}$ & $0.535^{\mathrm{c}}{ }_{2}$ & $0.299^{b}{ }_{1}$ & $0.344^{\mathrm{b}}{ }_{1}$ & $0.789^{\mathrm{c}}{ }_{3}$ \\
\hline
\end{tabular}

$\mathrm{a}, \mathrm{b}, \mathrm{c}$ - means followed by the same letter within the same species and different temperature are not significantly different at $\mathrm{P}<0.05$.

1,2,3- means followed by the same number within the same temperature between species are not significantly different at $\mathrm{P}<0.05$.

Germination of $C$. campestris seeds was not recorded at temperature 17, while other treatments showed different germination rates, ranging between 33.7 and $59.6 \%$ for coefficients $23^{\circ} \mathrm{C}$ and $32^{\circ} \mathrm{C}$, respectively (Figure 1). The results showed that there was a significant difference in the mean germination time between treatments and ranged between 4.51 and 8.36 days in treatments $32^{\circ} \mathrm{C}$ and $23^{\circ} \mathrm{C}$, respectively (Table 1 ). There was no significant difference in germination speed between treatments 28 and 32 and the lowest germination speed was 0.778 germinated seeds/day in treatment of $23^{\circ} \mathrm{C}$ (Table 2). The daily growth rate of the seedlings recorded significant differences between the treatments, and the lowest daily mean was 0.231 at $23^{\circ} \mathrm{C}$ while $0.789 \mathrm{~cm} /$ day at $32^{\circ} \mathrm{C}$ (Table 3 ).

\section{CONCLUSION}

The tested species showed a different response to temperature, and the differences between the germination ratios of the species decreased with increasing temperatures, and the highest germination percentage was for $A$. retroflexus, while the lowest germination rate was in $C$. campestris. The lowest mean germination time was in the treatment of $32^{\circ} \mathrm{C}$ for $A$. retroflexus and the largest in the treatment of $E$. maculata in the treatment of $23^{\circ} \mathrm{C}$ with significant differences between species. The highest germination speed was 9.6 germinated seeds/day obtained from A. retroflexus while the lowest germination speed was in E. maculata 0.2 germinated seeds/day. The species showed great differences in the speed of germination at the same temperatures. The highest daily growth rate achieved by $C$. campestris was $0.789 \mathrm{~cm} /$ day, while the lowest daily growth rate was $0.123 \mathrm{~cm} /$ day for $P$. oleracea, with significant differences between species at the same temperatures. 


\section{REFERENCES}

[1] AL SAKRAN M., Almhemed K., DAL S., USTUNER T. (2020) Test the Effect of Some Methods of Breaking the Dormancy on the Germination and Growth of Johnson Grass Seed (Sorghum halepense (L.) Pers.). International Journal of Innovative Science and Research Technology. Volume 5, Issue 4, Pages 557 $-561$.

[2] ALMHEMED K, AL SAKRAN M, USTUNER T (2020); Effect of Seeds Age on Some Treatments Efficiency for Breaking of Dodder (Cuscuta campestris Yunck.) Seeds Dormancy; International Journal of Scientific and Research Publications (IJSRP) 10(04) (ISSN: 2250-3153).

[3] Chauhan B.S, Johnson D.E. (2009) Seed germination ecology of Portulaca oleracea L.: an important weed of rice and upland crops. Annals of Applied Biology. Volume155, Issue1, Pages 61-69.

[4] Ellis, R.H., Roberts, E.H. (1981). "The quantification of ageing and survival in orthodox seeds" Seed Science and Technology, 9: 373-409

[5] Fu J.J, Liu J., Yang L.Y, Miao Y.J. (2017) Effects of low temperature on seed germination, early seedling growth and antioxidant systems of the wild Elymus nutans Griseb. Journal of Agricultural Science and Technology 19(5):1113-1125.

[6] Ghorbani R., Seel W., Leifert C. (2017) Effects of environmental factors on germination and emergence of Amaranthus retroflexus. Weed Science, Volume 47, Issue, pp. 505-510.

[7] ISTA. (1999). International rules for seed testing. Seed science and Technology, 21:288 pp.

[8] Lawrence E. Steckel, Christy L. Sprague, Edward W. Stoller and Loyd M. Wax. (2004) Temperature Effects on Germination of Nine Amaranthus Species. Weed Science. Vol. 52, No. 2 (Mar. - Apr. 2004), pp. 217-221.

[9] Manoto I., Martha M. MFerreira \& GA Agenbag (2004) The effect of temperature on the germination of six selected weed species, South African Journal of Plant and Soil, 21:4, 214-219.

[10] Rayhaneh A., Reza Gh., Mohammad K.H., Bhagirath S. Ch., (2015) Germination of Spotted Spurge (Euphorbia maculata) Seeds in Response to Different Environmental Factors. Weed Science 63(2):150304135115003.

[11] Shaban, M. (2013) Effect of water and temperature on seed germination and emergence as a seed hydrothermal time model. International journal of Advanced Biological and Biomedical Research Volume 1, Issue 12, 2013: 1686-1691

[12]Ustuner, T. (2002) Niğde ve yöresi patates tarlalarında sorun olan yabanc1 ot türlerinin önemi, çimlenme biyolojileri ve mücadele olanakları üzerine araştırmalar. PhD thesis, Konya, Turkey. P121.

[13] Ustuner T, Cakir S. (2019) Dormancy Breaking Studies of Dodder (Cuscuta spp.) was Problem in Greenhouse Tomato, The Eurasia Proceedings of Science, Technology, Engineering \& Mathematics (EPSTEM), Volume 2, Pages 167-178.

Citation: Muhammad AL SAKRAN,et.al.,, "Study the Indicators of Germination and Growth of Some Species of Weeds under Different Thermal Conditions." International Journal of Research Studies in Agricultural Sciences (IJRSAS), 2020; 6(9), pp. 1-5, https://doi.org/10.20431/2454-6224.0609001

Copyright: (0) 2020 Authors. This is an open-access article distributed under the terms of the Creative Commons Attribution License, which permits unrestricted use, distribution, and reproduction in any medium, provided the original author and source are credited. 